\title{
Population status of the jaguar Panthera onca in one of its last strongholds in the Atlantic Forest
}

\author{
Ana Carolina Srbek-Araujo and Adriano Garcia Chiarello
}

\begin{abstract}
Remaining jaguar Panthera onca populations in the Atlantic Forest are restricted to eight regions, and all populations appear to be declining. We report on the status of one of the last populations in south-eastern Brazil. We monitored this population with camera traps during June 2005January 2013 in Vale Natural Reserve. We estimated an abundance of $9 \pm$ SE 1.98 jaguars (95\% CI 9-17) and a population density of $3.22 \pm$ SE 1.58 individuals per $100 \mathrm{~km}^{2}$ (95\% CI 1.29-7.98). Annual survival probability over a 5-year interval was $78 \%$ ( $95 \%$ CI 58-98) and the recapture probability was $62 \%$ ( $95 \%$ CI $42-79$ ). Although our results are among the highest densities reported for the jaguar in this biome, the future of the population is threatened by genetic deterioration and local threats, including the expansion of an existing highway and depletion of the jaguar's native prey base as a result of poaching, and will depend upon urgent implementation of conservation actions. The necessary actions include establishing gene flow with other compatible populations, increasing surveillance against poaching, continuing population monitoring of jaguars and their main prey species, and implementing mitigation measures in relation to the impacts of the highway on local fauna.
\end{abstract}

Keywords Brazil, camera trap, carnivores, conservation, Cormack-Jolly-Seber model, Panthera onca, spatially explicit capture-recapture model, survival probability

\section{Introduction}

The jaguar Panthera onca is the largest cat and predator western United States to northern Argentina (Seymour, 1989), its current range comprises approximately $46 \%$ of its original area (Sanderson et al., 2002; Zeller, 2007), and the species is categorized as Near Threatened on the

Ana Carolina Srbek-Araujo* (Corresponding author) Programa de Pósgraduação em Ecologia, Conservação e Manejo de Vida Silvestre, Instituto de Ciências Biológicas, Universidade Federal de Minas Gerais, Avenida Antônio Carlos, no. 6627, Bairro Pampulha, Belo Horizonte, Minas Gerais, CEP 31.270-901, Brazil. E-mail srbekaraujo@hotmail.com

Adriano Garcia Chiarello Departamento de Biologia, Faculdade de Filosofia Ciências e Letras de Ribeirão Preto, Universidade de São Paulo, Ribeirão Preto, São Paulo, Brazil

*Current address: Programa de Pós-graduação em Ecologia de Ecossistemas, Universidade Vila Velha, Rua Comissário José Dantas de Melo, no. 21, Bairro Boa Vista, Vila Velha, Espírito Santo, CEP 29.102-920, Brazil

Received 13 January 2015. Revision requested 24 March 2015.

Accepted 19 October 2015. First published online 28 March 2016.
IUCN Red List (Caso et al., 2008). In Brazil the highest population densities of the jaguar are in the Pantanal and in the Amazon basin (Silveira \& Crawshaw, 2008; Cavalcanti et al., 2012; Oliveira et al., 2012), and the most threatened population is in the Atlantic Forest (Sanderson et al., 2002; Beisiegel et al., 2012; Ferraz et al., 2012). In this biome the species is categorized as Critically Endangered (Cunha de Padua et al., 2013). The Atlantic Forest is also threatened and occupies only $15 \%$ of its original extent (FSOSMA \& INPE, 2014). Contributing to this problem, the remaining area comprises an estimated 245,000 fragments, of which $83 \%$ are $<50$ ha, and less than $1 \%$ are $>10,000$ ha (Ribeiro et al., 2009).

As a consequence of the fragmentation in the Atlantic Forest $<10 \%$ of the area is considered adequate to maintain jaguar populations (Ferraz et al., 2012), and this small fraction is also fragmented and isolated (Tôrres et al., 2008). Beisiegel et al. (2012) confirmed the presence of jaguars in only eight regions in the Atlantic Forest, within which populations are declining. The total population size estimated for the Atlantic Forest is $156-180$ reproductive individuals, and most locations have fewer than 50 mature individuals (Beisiegel et al., 2012). Thus, even if places occupied by jaguars remain unaltered in the future, gradual population decline in these fragments is likely to result in local extinction, and therefore urgent measures are needed to maintain viable populations (Tôrres et al., 2008). If no action is taken the Atlantic Forest may become the first tropical biome to lose its top predator (Galetti et al., 2013).

We describe the current status of the jaguar population in Vale Natural Reserve, an important private protected area in the state of Espírito Santo, south-eastern Brazil. This region has one of the last remaining jaguar populations in the Atlantic Forest and is the only area in the state in which this big cat may still be found. This population already has low genetic diversity, despite the existence of putatively unique alleles, emphasizing the importance of this population to maintain the genetic diversity of jaguars in the Atlantic Forest as a whole (Srbek-Araujo, 2013).

\section{Study area}

Vale Natural Reserve (22,711 ha; Fig. 1) is located between the municipalities of Linhares and Jaguaré and is adjacent to the Sooretama Biological Reserve (c. 24,250 ha), the Recanto das Antas Natural Heritage Private Reserve (2,202 ha) and the Mutum Preto Natural Heritage Private Reserve (379 ha). 


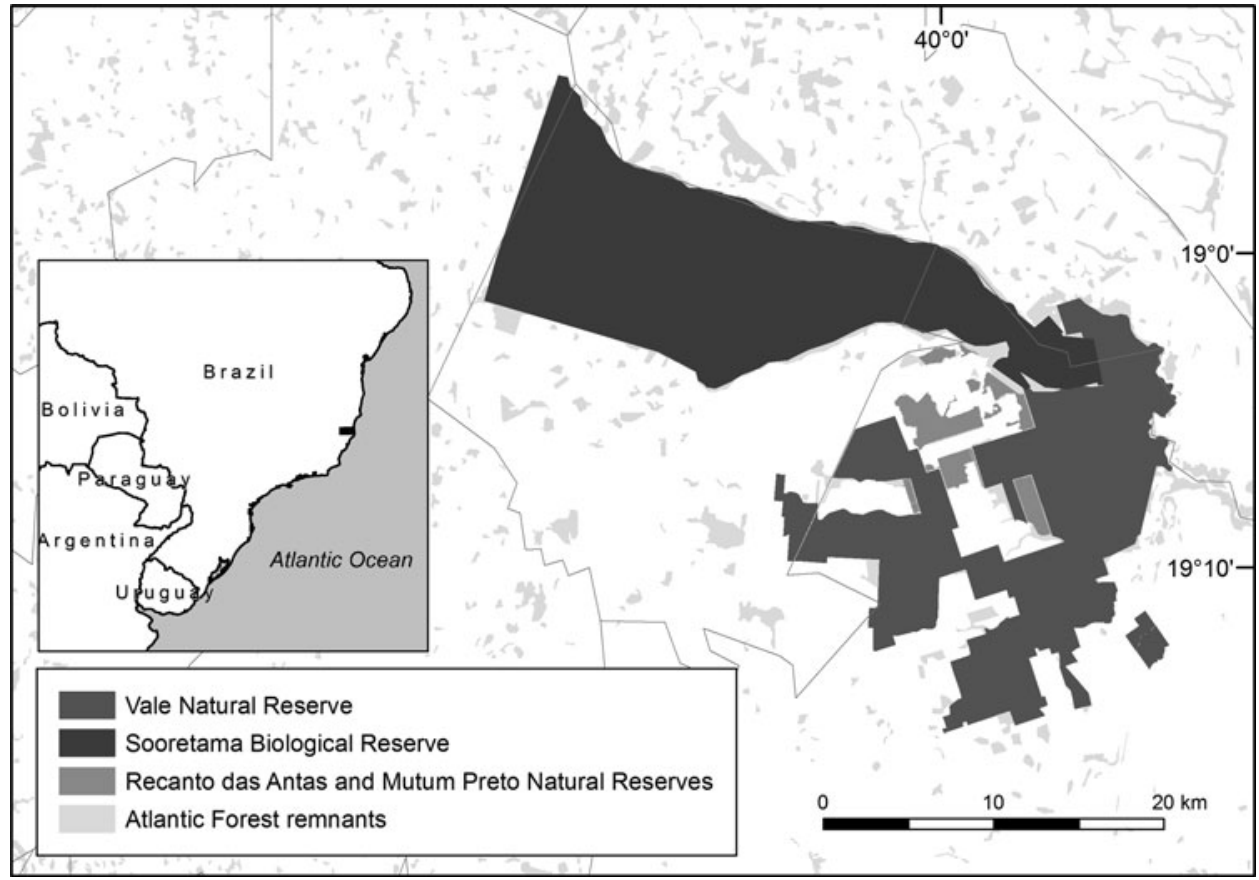

FIG. 1 The Linhares-Sooretama block, comprising the Vale Natural Reserve, the Sooretama Biological Reserve, the Recanto das Antas Natural Heritage Private Reserve and the Mutum Preto Natural Heritage Private Reserve, with surrounding forest remnants. The black rectangle on the inset indicates the location of the main map in Brazil.
Together these reserves form a continuous block of native vegetation (hereafter the Linhares-Sooretama block) that is crossed by the BR-101 highway and comprises $>10 \%$ of the remaining forest in the state of Espírito Santo (based on data available in FSOSMA \& INPE, 2014; Fig. 1).

Vale Natural Reserve includes a mosaic of habitats. Most of the Reserve comprises dense lowland forest (Tabuleiro forest) interspersed with less dense forest on sandy soils (Mussununga) and occasional native grassland (Campo nativo). There are some marshes along the larger streams. There are c. $126 \mathrm{~km}$ of 4-m wide unpaved roads within the Reserve. The Reserve is irregularly shaped (Fig. 1) and surrounded by agriculture (dominated by pasture, fruit and coffee). Since 2007 eucalyptus plantations have become more common nearby. For more details about the study area see Srbek-Araujo \& Chiarello (2013).

\section{Methods}

Jaguars were monitored during 54 months, in five sampling periods: June 2005-June 2006 (year 1), June 2006-August 2007 (year 2), August 2007-October 2008 (year 3), June 2009-February 2010 (year 4) and July 2012-January 2013 (year 5). We used CamTrakker game cameras (Cam-Trak South, Inc., Watkinsville, USA) in year 1, Tigrinus cameras (conventional model, Tigrinus Research Equipment, Timbó, Brazil) in years 2-4, and Bushnell Trophy Cam digital camera traps (Bushnell Inc., Overland Park, USA) in year 5 . In year 1 all trapping stations contained a pair of cameras facing each other. In the other years we used only one camera per trapping station. Camera traps were in use $24 \mathrm{~h} \mathrm{day}^{-1}$, without bait, and were checked and maintained every 30 days.

We divided the Reserve into three sub-areas (north, south, west), with camera traps always placed in lowland forest. We placed camera traps at predetermined, regularly spaced points to ensure systematic sampling of the study area (Fig. 2; Table 1). In year 1 we installed cameras along the internal unpaved roads, with distances between sampling points determined by the size of the smallest home range estimated for the jaguar (Silver et al., 2004). The equipment was also installed on unpaved roads in years 4 and 5 , and in years 2 and 3 camera traps were installed off roads and separated by longer distances to include a larger area of the Reserve. The sampling design is summarized in Table 1.

Individual jaguars were identified based on specific rosette and spot patterns (both sides detected by the pairs of cameras in year 1, and comparison of left or right flanks in other sampling years), as in previous studies with big cats (e.g. Karanth, 1995; Karanth \& Nichols, 1998; Wallace et al., 2003; Silver et al., 2004; Soisalo \& Cavalcanti, 2006). Poor-quality photographs were categorized as unidentified individuals.

To estimate sampling effort we multiplied the number of camera traps (or pairs of cameras) by the number of sampling days (i.e. the time between the first and last records in each month of sampling, subtracting any time periods when both cameras of a pair (year 1) or single cameras (other sampling years) malfunctioned; Srbek-Araujo \& Chiarello, 2005). The capture success was estimated by 


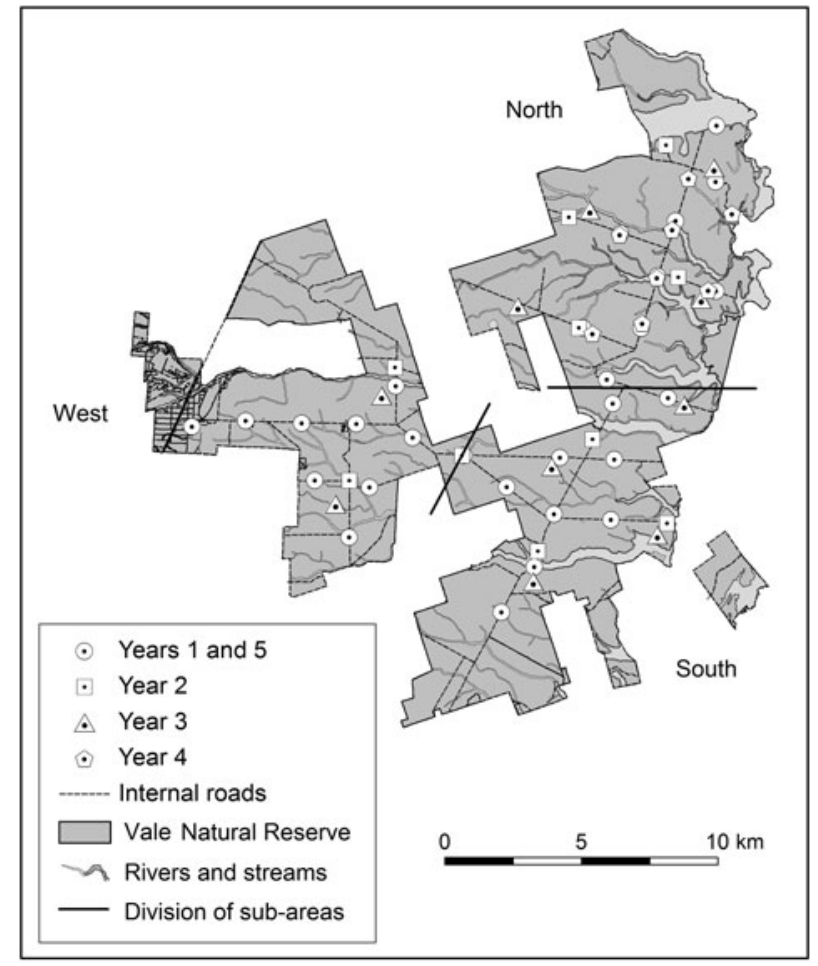

Fig. 2 The locations of camera traps in the south, west and north sub-areas of Vale Natural Reserve in Espírito Santo, south-eastern Brazil (Fig. 1), for five sampling intervals during June 2005-January 2013.

dividing the number of records by the sampling effort and multiplying the result by 100 (Srbek-Araujo \& Chiarello, 2005). To select valid records we considered only the first photograph of a jaguar obtained from the same trapping station within a period of 1 hour (Srbek-Araujo \& Chiarello, 2013).

Because of the small sample sizes we were unable to use robust design or closed population models in MARK v. 8.o (White \& Burnham, 1999; Cooch \& White, 2012). We thus estimated abundance using CAPTURE, which is embedded in MARK. We selected the best 3-month period in terms of number of captures and recaptures during year 1 (i.e. JulyOctober 2005). Encounter data were insufficient for running the closure test in CAPTURE (Otis et al., 1978; White et al., 1982). However, the closure assumption passed an alternative test that could be run with our data, the Stanley \& Burnham (1999) closure test in CLOSETEST $\left(\chi^{2}=0.166\right.$, $\mathrm{df}=2, \mathrm{P}=0.920)$.

To estimate density we used spatially explicit capture-recapture models in DENSITY v. 5.o (Efford et al., 2004). Only data from year 1 were used because this was the most robust dataset (with a higher number of records of jaguars), and only records from the north sub-area (first 2 months of sampling) were included. For spatial analysis we used a shape file of the Linhares-Sooretama block and fragments connected to the study area as potential habitat. Jaguars have an aversion towards disturbed habitat types and avoid human-dominated areas, such as intensively managed open pastures (Cullen et al., 2013) and crop plantations (Sollmann et al., 2011), which characterize most of the landscape surrounding the Linhares-Sooretama block. The forest fragments surrounding the sampling area are few and small (Fig. 1), and there is as yet no evidence that jaguars use these areas. However, there are some small remnants of riparian vegetation along stretches of rivers from the western portion of the Reserve towards its northern area. We believe jaguars may use these areas as movement corridors but the areas may not be of importance as hunting grounds. We included these fragments and those connected to the larger forest block in the shape file of potential habitat. We estimated density using maximum likelihood, with proximity detector type, half-normal detection model, full likelihood and Poisson distribution (Efford et al., 2004). Estimates were generated for sequential buffer levels, and this operation was repeated until the density values became stable, which occurred within a $10 \mathrm{~km}$ buffer.

We estimated annual survival probability (phi) and recapture probability (p) using data from years 1, 4 and 5 with an open population model (Cormack-Jolly-Seber; Cormack, 1964; Jolly, 1965; Seber, 1965) in MARK. We discarded years 2 and 3 in this analysis because of the low number of individuals captured and recaptured, which probably resulted from sampling off unpaved roads. In years 1, 4 and 5 the cameras were placed along roads so there was no need to assess the effect of camera placement (on or off unpaved roads). Initially, we tried to assess the effect of sex on both survival and recapture probabilities, treating sex either as a covariate or as a group, and using only data from eight individuals whose sex was known. However, given the poor performance of all preliminary models, we opted not to discriminate on the basis of sex, and used instead a data set containing an additional individual whose sex was unknown. We then assessed the effect of time and effort (camera-trap days). We used trimesters (one sampling occasion $=12$ weeks) as sampling occasions to guarantee closure within sampling periods. To convert trimestral survival to annual survival we used the estimated parameter (phi) to the power of 4 : (trimestral phi) $)^{4}=$ annual phi. To convert trimestral standard errors to annual standard errors we used the Delta method adjustment, following Powell (2007). We adjusted for varying time intervals (sampling intervals within year $\neq$ sampling intervals between years) during data set up in $M A R K$. We judged it necessary to assess the influence of sampling effort as this varied considerably between the selected years (Table 1), and we did this by changing the parameter indexes (for $\mathrm{p}$, phi or both) in the parameter index matrices in MARK (see details in White \& Burnham, 1999). In a preliminary analysis we compared models with the same parameter index for sampling intervals within years (three parameter indexes, one for each 
TABLE 1 Details of camera-trap sampling regimes in Vale Natural Reserve, Espírito Santo, south-eastern Brazil (Fig. 2), during June 2005January 2013, with sampling period, sub-area covered, camera location, number of sampling stations, duration of sampling, details of sampling time/sampling station, and the mean distance between adjacent cameras.

\begin{tabular}{|c|c|c|c|c|c|c|}
\hline Sampling period & $\begin{array}{l}\text { Coverage } \\
\text { (i.e. sub-area) }\end{array}$ & Location & $\begin{array}{l}\text { No. of sampling } \\
\text { stations }\end{array}$ & $\begin{array}{l}\text { Duration } \\
\text { (months) }\end{array}$ & $\begin{array}{l}\text { Sampling time/ } \\
\text { sampling station }\end{array}$ & $\begin{array}{l}\text { Mean spacing } \\
\text { (min. spacing), } \mathrm{km}\end{array}$ \\
\hline $\begin{array}{l}\text { Year } 1 \\
\text { (June 2005-June 2006) }\end{array}$ & $\begin{array}{l}\text { North, South, } \\
\text { West }\end{array}$ & Internal roads & $\begin{array}{l}30 \text { (10 per } \\
\text { sub-area) }\end{array}$ & 12 & $\begin{array}{l}4 \text { months per sub- } \\
\text { area ( } 2 \text { months each } \\
\text { wet \& dry season) }\end{array}$ & $2.35(1.96)$ \\
\hline $\begin{array}{l}\text { Year } 2 \\
\text { (June 2006-Aug. 2007) }\end{array}$ & $\begin{array}{l}\text { North, South, } \\
\text { West }\end{array}$ & $\begin{array}{l}100-200 \mathrm{~m} \\
\text { from internal } \\
\text { roads }\end{array}$ & 10 & 14 & Fixed stations & $4.40(4.05)$ \\
\hline $\begin{array}{l}\text { Year } 3 \\
\text { (Aug. 2007-Oct. 2008) }\end{array}$ & $\begin{array}{l}\text { North, South, } \\
\text { West }\end{array}$ & $\begin{array}{l}\text { Forest } \\
\text { interior }\end{array}$ & 10 & 14 & Fixed stations & $5.14(3.93)$ \\
\hline $\begin{array}{l}\text { Year } 4 \\
\text { (June 2009-Feb. 2010) }\end{array}$ & North & Internal roads & 8 & 8 & Fixed stations & $2.31(1.75)$ \\
\hline $\begin{array}{l}\text { Year } 5 \\
\text { (July 2012-Jan. 2013) }\end{array}$ & $\begin{array}{l}\text { North, South, } \\
\text { West }\end{array}$ & Internal roads & $\begin{array}{l}30(10 \text { per } \\
\text { sub-area })^{*}\end{array}$ & 6 & $\begin{array}{l}2 \text { months per } \\
\text { sub-area }\end{array}$ & $2.35(1.96)$ \\
\hline
\end{tabular}

* The same points sampled during year 1

year) with models containing one additional parameter index (four parameter indexes: three for sampling intervals within years (one for each) and a fourth parameter for indexing sampling intervals between years). We opted for the second parameterization (i.e. with an additional parameter) as, apart from being biologically more realistic, it estimated parameters with better precision (lower standard errors). We assessed model fit by calculating the overdispersion parameter (c-hat) for the global (most parameterized) model using the bootstrap goodness of fit procedure in MARK. We calculated c-hat by dividing the observed deviance of the global model [phi(time) $\mathrm{p}$ (time)] by the mean value of the simulated deviances ( $\mathrm{n}=999$ runs), as recommended by Cooch \& White (2012). We ranked models using the quasi Akaike information criterion corrected for small sample sizes (QAICc), after adjusting the standard errors of the estimated parameters with the overdispersion parameter, which was just slightly greater than 1 (see results). Only models with $\Delta$ QAICc $<2$ were considered to be competing (Burnham \& Anderson, 1998).

\section{Results}

In a total of 12,007 trap days we captured 144 independent photographs of jaguars: 79 of males $(55 \%), 52$ of females $(36 \%)$ and 13 of individuals of unidentified sex (9\%). The capture success rate was 1.2 captures per 100 trap days. Most photographs were taken along roads, especially in years 1 and 4 . Nine individuals were identified in the Reserve during the study period (year $1, \mathrm{n}=8$; year $2, \mathrm{n}=3$; year $3, n=2$; year $4, n=4$; year $5, n=2$ ), with the highest number of records in the first year. Although no cubs were photographed during the entire study, two subadults were recorded in year 1 . Of the nine jaguars identified in the Reserve, three were males, five were females and the sex of one could not be determined. Only one new individual (sex unidentified) was recorded after the first year of sampling, during year 3. Based on the data from year 1, when we recorded the highest number of individuals, the adult male : female ratio was $1: 2$.

The selection algorithm of CAPTURE indicated the null (Mo) and heterogeneity (Mh) models were the two best models. Capture probability ( $\mathrm{p}$-hat) was estimated to be $0.226(23 \%)$ and $0.176(18 \%)$, and abundance was estimated to be $7 \pm \mathrm{SE} 0.638$ (95\% CI 7-9) and $9 \pm \mathrm{SE} 1.982$ jaguars (95\% CI 9-17) for the Mo and Mh models, respectively. Population density was estimated to be $3.219 \pm$ SE 1.575 individuals per $100 \mathrm{~km}^{2}$ (95\% CI 1.299-7.980; go $=0.287 \pm 0.072$; sigma $=3,447.533 \pm 959.238$ ).

Results from the open population analysis (CormackJolly-Seber) for estimating annual survival probability (phi) and recapture probability (p) during the 5 years of the study are shown in Table 2 . The goodness of fit procedure (bootstrap goodness of fit) yielded c-hat $=1.183$, which indicates that the top-ranked models are reasonably good (i.e. there is no additional binomial variation). The null model, phi(.) $\mathrm{p}($.$) , and the model in which recapture varied accord-$ ing to sampling effort, phi(.) p(effort), were the top two competing models according to AIC conventions. However, comparing the QAIC weight, the top model is only 1.07 times more likely than the second model ( 0.495 vs 0.462 ). The third-ranked model, with a constant $\mathrm{p}$ and an effortvarying phi, was less supported and much less plausible $(\triangle \mathrm{QAICc}=5.728)$. All the remaining models had virtually no support $(\triangle \mathrm{QAICc}>7)$. Annual survival probability was $0.778 \pm$ SE 0.101 (95\% CI $0.580-0.976)$ and recapture probability was $0.623 \pm$ SE $0.098(95 \% \mathrm{CI}-0.422-0.789)$ for the 
TABLE 2 Models for estimation of annual survival probability (phi) and recapture probability (p) for jaguars Panthera onca in Vale Natural Reserve, Espírito Santo, south-eastern Brazil (Fig. 2), during a 5-year interval (years 1, 4 and 5, Table 1) using Cormark-Jolly-Seber analysis in MARK, with quasi Akaike information criterion corrected for small sample size (QAICc), $\triangle \mathrm{QAICc}$, model weight (QAICc weight), model likelihood, number of parameters and quasi deviance. Models are ranked from lowest to highest QAICc. Estimates of annual survival probability are given for the best-ranked models $(\Delta \mathrm{QAICc}<2)$.

\begin{tabular}{|c|c|c|c|c|c|c|c|}
\hline Model $^{\star}$ & QAICc & $\Delta \mathrm{QAICc}$ & $\begin{array}{l}\text { QAICc } \\
\text { weight }\end{array}$ & $\begin{array}{l}\text { Model } \\
\text { likelihood }\end{array}$ & $\begin{array}{l}\text { No. of } \\
\text { parameters }\end{array}$ & $\begin{array}{l}\text { Quasi } \\
\text { deviance }\end{array}$ & $\begin{array}{l}\text { Annual survival probability } \\
\text { phi } \pm \text { SE }(95 \% \mathrm{CI})\end{array}$ \\
\hline phi(.) p(.) & 67.2579 & 0.0000 & 0.4948 & 1.0000 & 2 & 42.3337 & $0.778 \pm 0.101(0.580-0.976)$ \\
\hline phi(.) p(effort) & 67.3944 & 0.1365 & 0.4622 & 0.9340 & 5 & 34.6480 & $0.727 \pm 0.097(0.537-0.917)$ \\
\hline phi(effort) p(.) & 72.9858 & 5.7279 & 0.0282 & 0.0571 & 5 & 40.2395 & \\
\hline phi(effort) p(effort) & 74.3013 & 7.0434 & 0.0146 & 0.0295 & 8 & 31.7771 & \\
\hline phi(.) p $(\mathrm{t})$ & 83.3468 & 16.0889 & 0.0002 & 0.0003 & 10 & 32.8226 & \\
\hline phi(t) $\mathrm{p}()$. & 87.6983 & 20.4404 & 0.0000 & 0.0000 & 10 & 37.1741 & \\
\hline phi(t) p(effort) & 92.4388 & 25.1809 & 0.0000 & 0.0000 & 13 & 26.7568 & \\
\hline phi(effort) $\mathrm{p}(\mathrm{t})$ & 94.3542 & 27.0963 & 0.0000 & 0.0000 & 13 & 28.6722 & \\
\hline $\operatorname{phi}(\mathrm{t}) \mathrm{p}(\mathrm{t})$ & 130.4703 & 63.2124 & 0.0000 & 0.0000 & 18 & 25.0890 & \\
\hline
\end{tabular}

${ }^{*} t$, trimesters of sampling; effort, sampling effort; (.), parameter constant

top-ranked (constant) model. The second-ranked model indicated that recapture probability varied according to sampling effort for each year, but the precision of estimated parameters was low: $\mathrm{p}($ year 1$)=0.444 \pm \mathrm{SE} 0.125(95 \% \mathrm{CI}$ 0.229-0.683); p(year 4) = $0.875 \pm$ SE 0.127 (95\% CI $0.418-$ 0.986); p (year 5) $=1.00 \pm$ SE $0.00 \quad(95 \%$ CI $1.00-1.00)$; $\mathrm{p}$ (transitional years $1-4$ and $4-5)=1.00 \pm$ SE $0.00(95 \%$ CI 1.00-1.00).

\section{Discussion}

Here, as elsewhere (Sollmann et al., 2011), jaguars were photographed more often on roads than off roads. A similar pattern has also been recorded for other felids, including pumas Puma concolor and ocelots Leopardus pardalis (Trolle \& Kéry, 2005; Dillon \& Kelly, 2007). This may be attributable to habitat-dependent detectability; for example, as a consequence of different behavioural patterns in each habitat type (Srbek-Araujo \& Chiarello, 2013). Apparently, however, there are sex-specific differences in habitat use, with female jaguars tending to avoid roads whereas males seem to be either indifferent to roads (Conde et al., 2010) or selectors of roads. This may partly explain the higher number of records of males in this study. Additionally, females have smaller territories than males, thus reducing their capture probability and leading to lower estimates of female abundance (Salom-Pérez et al., 2007).

We recorded a higher number of photographs per individual than other studies (Soisalo \& Cavalcanti, 2006; Astete, 2008), and a higher number of photographs of males, despite higher numbers of individual females being photographed in the Reserve. The higher number of individual females photographed contrasts with the findings of other studies (Wallace et al., 2003; Silver et al., 2004; Soisalo \& Cavalcanti, 2006; Salom-Pérez et al., 2007;
Sollmann et al., 2011; Astete, 2012). The sex ratio during the first year of the study was similar to that found in another protected area in the Atlantic Forest (Cullen, 2006), although camera trap studies tend to result in sex ratios biased towards males (Soisalo \& Cavalcanti, 2006; Salom-Pérez et al., 2007; Astete, 2012). Although two subadults were recorded in the first year, the absence of cubs in the Reserve is at first alarming. However, other studies using camera traps have also found few (Soisalo \& Cavalcanti, 2006) or no cubs (Cullen, 2006), and this may be a result of a combination of mother-infant behaviour and the limitations of camera trapping (Karanth, 2002).

This is the first population estimate for jaguars in the Linhares-Sooretama block and the state of Espírito Santo. Although we report the abundance results of the two top models, the abundance estimator of the Mh model is known to be less sensitive to violations of the underlying assumptions (Otis et al., 1978). As this model facilitates a different capture probability for each individual, it has proved to be more realistic biologically and to perform best for other felids (Karanth, 1995; Karanth \& Nichols, 1998). We therefore have more confidence in the Mh estimates $(9 \pm \mathrm{SE}$ 1.982 jaguars, $95 \% \mathrm{CI} 9-17$ ). Although the jaguar population in Vale Natural Reserve is small, the density is among the highest estimated for jaguars in the Atlantic Forest (3.2 individuals per $100 \mathrm{~km}^{2}$ ). The highest reported density was in Iguaçu National Park in the 199os, with 3.7 individuals per $100 \mathrm{~km}^{2}$ (Crawshaw, 1995), but a more recent analysis suggests a lower density for the same area (c. 1 individual per $100 \mathrm{~km}^{2}$; Paviolo et al., 2008). For other areas within the Atlantic Forest, density estimates are $<_{1}$ individual per 100 $\mathrm{km}^{2}$ (Beisiegel et al., 2012), except in Morro do Diabo State Park, where the density is $2.2-2.5$ individuals per $100 \mathrm{~km}^{2}$ (Cullen, 2006).

Higher densities have been found in the Brazilian Pantanal (6.7 individuals per $100 \mathrm{~km}^{2}$; Soisalo \& 
Cavalcanti, 2006), in the Brazilian Amazon (17.9; Ramalho, 2012) and in Central America (4.6 in Mexico, Torre \& Medellín, 2011; 8.8 in Belize, Silver et al., 2004). These higher densities are probably attributable to greater environmental productivity and prey species abundance (Karanth et al., 2004, 2006; Ramalho, 2012). We suggest, therefore, that the jaguar abundance in Vale Natural Reserve is a consequence of the abundance of prey in this particular Atlantic Forest vegetation type. It has been recognized that mammal abundance (species $>1 \mathrm{~kg}$ ) is higher in lowland forests (as is the case in the Reserve) and in semideciduous forests than in other vegetation types of the Atlantic Forest (Galetti et al., 2009). Remains of domestic animals have never been found in jaguar faecal samples from the Reserve (Facure \& Giaretta, 1996; Srbek-Araujo, 2013), which, together with the absence of recent predation by jaguars on livestock near the Reserve (Srbek-Araujo, 2013), suggests there is adequate availability of native prey in the region (there are, however, no studies on prey numbers in the area). The last report of livestock predation dates from 1971, when two jaguars were killed in retaliation for taking cattle (Lorenzutti \& Almeida, 2006). Nonetheless, the potential risk of livestock predation should not be disregarded, as the loss of jaguars to hunters in retaliation for taking livestock is one of the main causes of jaguar mortality in the Pantanal (Cavalcanti et al., 2012).

Studies of population dynamics specifically regarding survival rates in large cats are rare because of the difficulty of gathering sufficient data over time. These include one study of tigers Panthera tigris in southern India (Karanth et al., 2006) and one of jaguars in the Caatinga, in northeastern Brazil (Astete, 2012). In India, tiger survival was estimated to be $77 \%$ per year (based on a 12-year data set), with a recapture probability of $18 \%$ (Karanth et al., 2006). Our estimate for jaguar survival $(78 \%)$ is comparable with that of jaguars in the Serra da Capivara National Park (82\% for females and $86 \%$ for males, based on a 3-year data set; Astete, 2012). However, recapture probability was lower in the Reserve (62\%) than in the Caatinga (95\% for females, $98 \%$ for males; Astete, 2012). These results suggest that the recapture probability is variable but that the annual survival probability of big cats may be c. $80 \%$.

Population trends in large carnivores may include delays between cause and effect among factors that influence population dynamics (Schaller, 1972), and thus there may be a time interval between population fluctuations of predators and their prey (Utida, 1957). In the Reserve, for example, prey populations may decline as a consequence of poaching pressure in combination with the presence of other cats (puma and ocelot) whose diets overlap with that of the jaguar, thereby increasing competition and reducing the availability of prey for cat species in general. Poaching intensity is assumed to be relatively low in the Reserve because of ongoing surveillance activities in the area (Chiarello, 2000), although this may gradually become a more serious problem as a result of growth of the surrounding villages and cities and the reduction of anti-poaching patrol activities. Jaguars are also threatened by hunters, who may shoot them out of fear or as target game (for the fur trade or sport poaching), as documented historically in Espírito Santo. A jaguar was killed by hunters in 1958 in the municipality of Sooretama (Lorenzutti \& Almeida, 2006), and jaguar hunting continued in the region until the mid 1980 . Jaguar mortality as a result of collisions with automobiles is also potentially significant locally because highway BR-101 bisects the Linhares-Sooretama block. A female jaguar was killed on this stretch of the highway in 2000 (Srbek-Araujo et al., 2015). The pending expansion of the highway, to double the number of lanes, has been approved but the potential environmental impact in the LinharesSooretama region has not yet been studied, nor have any mitigation plans been drawn up to avoid or reduce the risk of road-kill in this forested region (Srbek-Araujo et al., 2015).

As so few jaguars remain in the Linhares-Sooretama block, some form of intervention will be necessary to maintain the viability of this population in the long term. Results from a genetic study show low levels of genetic diversity and significant genetic differentiation from other Atlantic Forest populations (Srbek-Araujo, 2013). There is therefore an urgent need to implement a management programme to re-establish gene-flow between this and other compatible jaguar populations in the Atlantic Forest. Without active management of the remaining populations as a metapopulation (Srbek-Araujo, 2013), the genetic diversity of the jaguars in Vale Natural Reserve, as well as other populations in the Atlantic Forest, will decline further and they will suffer the consequences of inbreeding. This measure must be concurrent with the implementation of other important actions, including systematic monitoring of this jaguar population and of its main prey species (including periodic assessment of the jaguar's diet in the study area), together with increased surveillance against poaching, to ensure the protection of jaguars and the maintenance of the local native prey base. Mitigation actions must also be implemented to reduce the incidence of road-kill, given the planned expansion of highway BR-101. Potential alternatives for consideration include not adding additional lanes to the stretch of highway traversing the Linhares-Sooretama block, the deviation of the current route, and the construction of overpasses for fauna at critical points (Srbek-Araujo et al., 2015). Restoration of forest in areas used for pasture and agricultural activity on private properties close to the Reserve could increase the habitat available for prey species and jaguars, contributing to the conservation of the species, but this represents a complex economic issue.

As jaguars in other regions are probably facing similar problems to those in the Linhares-Sooretama block, the 
actions we propose to conserve the jaguar in the state of Espírito Santo may be useful or even necessary for jaguar conservation in other Atlantic Forest reserves as well as in the biome as a whole.

\section{Acknowledgements}

We thank Hermano José Del Duque Júnior, Eduardo de Rodrigues Coelho, Jesuíno Barreto, Braz Guerini and José Simplício dos Santos for help with field activities. We thank James J. Roper, who reviewed the text in its entirety and provided helpful suggestions, and anonymous reviewers for their valuable critiques. AGC is sponsored by $\mathrm{CNPq}$ (Conselho Nacional de Desenvolvimento Científico e Tecnológico); 305902/2014-8.

\section{References}

Astete, S. (2008) Ecologia da onça-pintada nos Parques Nacionais Serra da Capivara e Serra das Confusões, Piauí. MSc thesis. Universidade de Brasília, Brasília, Brazil. Http://repositorio.unb.br/ bitstream/10482/6268/1/2008_SamuelEnriqueAstetePerez.pdf [accessed 16 August 2014].

Astete, S. (2012) Ecologia e conservação da onça-pintada e da onça-parda no Parque Nacional Serra da Capivara, Piauí. PhD thesis. Universidade de Brasília, Brasília, Brazil. Http://www.pgecl. unb.br/images/sampledata/arquivos/teses/2011a2013/2012/SAMUEL \%2oENRIQUE\%20ASTETE\%2oPEREZ.pdf [accessed 16 August 2014].

Beisiegel, B.M., Sana, D.A. \& Moraes, JR, E.A. (2012) The jaguar in the Atlantic Forest. Cat News Special Issue, 7, 14-18.

Burnham, K.P. \& Anderson, D.R. (1998) Model Selection and Multimodel Inference: A Practical Information-Theoretic Approach. 2nd edition. Springer-Verlag, New York, USA.

Caso, A., Lopez-Gonzalez, C., Payan, E., Eizirik, E., De Oliveira, T., Leite-Pitman, R. et al. (2008) Panthera onca. In The IUCN Red List of Threatened Species 2008: e.T15953A5327466. Http://dx.doi.org/10.2305/IUCN.UK.2008.RLTS.T15953A5327466.en [accessed 10 November 2015].

Cavalcanti, S.M.C., Azevedo, F.C.C., Tomás, W.M., Boulhosa, R.L.P. \& Crawshaw, Jr, P.G. (2012) The status of the jaguar in the Pantanal. Cat News Special Issue, 7, 29-34.

Chiarello, A.G. (2000) Influência da caça ilegal sobre mamíferos e aves das matas de tabuleiro do norte do estado do Espírito Santo. Boletim do Museu de Biologia Mello Leitão, 11/12, 229-247.

Conde, D.A., Colchero, F., Zarza, H., Christensen, Jr, N.L., Sexton, J.O., Manterola, C. et al. (2010) Sex matters: modeling male and female habitat differences for jaguar conservation. Biological Conservation, 143, 1980-1988.

Cooch, E. \& White, G.C. (2012) Program MARK: A Gentle Introduction. Cornell University, New York, USA.

CORMACK, R.M. (1964) Estimates of survival from the sighting of marked animals. Biometrika, 51, 429-438.

Crawshaw, JR, P.G. (1995) Comparative ecology of ocelot (Felis pardalis) and jaguar (Panthera onca) in a protected subtropical forest in Brazil and Argentina. PhD thesis. University of Florida, Gainesville, USA. Http://books.google.com.br/books/about/ Comparative_Ecology_of_Ocelot_Felis_Pard.html?id= L-HitgAACAAJ\&redir_esc=y [accessed 16 August 2014].
Cullen, JR, L. (2006) Jaguars as landscape detectives for the conservation of Atlantic Forests in Brazil. PhD thesis. University of Kent, Canterbury, UK. Http://www.carnivoreconservation.org/files/ thesis/cullen_2006_phd.pdf [accessed 16 August 2014].

Cullen, Jr, L., SAna, D.A., Lima, F., Abreu, K.C. \& UeZu, A. (2013) Selection of habitat by the jaguar, Panthera onca (Carnivora: Felidae), in the upper Paraná River, Brazil. Zoologia, 30, 379-387.

Cunha de Padua, R., Desdiez, A. \& Cavalcanti, S.M.C. (eds) (2013) Plano de Ação Nacional para a Conservação da Onça-pintada. Instituto Chico Mendes de Conservação da Biodiversidade, Brasília, Brazil. Http://www.icmbio.gov.br/portal/images/stories/docs-planode-acao/pan-onca-pintada/livro-onca-pintada.pdf [accessed 24 October 2014].

Dillon, A. \& Kelly, M.J. (2007) Ocelot Leopardus pardalis in Belize: the impact of trap spacing and distance moved on density estimates. Oryx, 41, 469-477.

Efford, M.G., Dawson, D.K. \& Robbins, C.S. (2004) DENSITY: software for analysing capture-recapture data from passive detector arrays. Animal Biodiversity and Conservation, 27, 217-228.

Facure, K.G. \& Giaretta, A.A. (1996) Food habits of carnivores in a coastal Atlantic forest of southeastern Brazil. Mammalia, 60, 499-502.

Ferraz, K.M.P.M.B., Beisiegel, B.M., Paula, R.C., Sana, D.A., Campos, C.B., Oliveira, T.G. \& Desbiez, A.L.J. (2012) How species distribution models can improve cat conservation-jaguars in Brazil. Cat News Special Issue, 7, 38-42.

FSOSMA \& INPE (2014) Atlas dos Remanescentes Florestais da Mata Atlântica-Período 2012-2013. Fundação SOS Mata Atlântica \& Instituto Nacional de Pesquisas Espaciais, São Paulo, Brazil. Http:// www.sosma.org.br/wp-content/uploads/2014/05/atlas_2012-2013_ relatorio_tecnico_20141.pdf [accessed 18 December 2014].

Galetti, M., Eizirik, E., Beisiegel, B., Ferraz, K., Cavalcanti, S., Srbek-Araujo, A.C. et al. (2013) Atlantic rainforest's jaguars in decline. Science, 342, 930.

Galetti, M., Giacomini, H.C., Bueno, R.S., Bernardo, C.S.S., Marques, R.M., Bovendorp, R.S. et al. (2009) Priority areas for the conservation of Atlantic Forest large mammals. Biological Conservation, 142, 1229-1241.

Jolly, G.M. (1965) Explicit estimates from capture-recapture data with both death and immigration-stochastic model. Biometrika, 52, 225-247.

Karanth, K.U. (1995) Estimating tiger Panthera tigris populations from camera-trap data using capture-recapture models. Biological Conservation, 71, 333-338.

Karanth, K.U. (2002) Monitoring Tigers and Their Prey: A Manual for Wildlife Researchers, Managers and Conservationists in Tropical Asia. Centre for Wildlife Studies, Bangalore, India.

KarAnth, K.U. \& Nichols, J.D. (1998) Estimation of tiger densities in India using photographic captures and recaptures. Ecology, 79, 2852-2862.

Karanth, K.U., Nichols, J.D., Kumar, N.S. \& Hines, J.E. (2006) Assessing tiger population dynamics using photographic capturerecapture sampling. Ecology, 87, 2925-2937.

Karanth, K.U., Nichols, J.D., Kumar, N.S., Link, W.A. \& Hines, J.E. (2004) Tigers and their prey: predicting carnivore densities from prey abundance. PNAS, 101, 4854-4858.

Lorenzutti, R. \& Almeida, A.P. (2006) A coleção de mamíferos do Museu Elias Lorenzutti em Linhares, Estado do Espírito Santo, Brasil. Boletim do Museu de Biologia Mello Leitão, 19, 59-74.

Oliveira, T.G., Ramalho, E.E. \& Paula, R.C. (2012) Red List assessment of the jaguar in Brazilian Amazonia. Cat News Special Issue, 7, 8-13.

Otis, D.L., Burnham, K.P., White, G.C. \& Anderson, D.R. (1978) Statistical inference from capture data on closed animal populations. Wildlife Monographs, 62, 1-135. 
Paviolo, A., De Angelo, C.D., Di Blanco, Y.E. \& Di Bitetti, M.S. (2008) Jaguar Panthera onca population decline in the Upper Paraná Atlantic Forest of Argentina and Brazil. Oryx, 42, 554-561.

Powell, L.A. (2007) Approximating variance of demographic oarameters using the Delta method: a reference for avian biologists. The Condor, 109, 949-954.

Ramalho, E.E. (2012) Jaguar (Panthera onca) population dynamics, feeding ecology, human induced mortality, and conservation in the Várzea Floodplain Forests of Amazonia. PhD thesis. University of Florida, Gainesville, USA. Http://www.mamiraua.org.br/cms/ content/public/documents/publicacao/a383d23a-1dao-4929-a65fb64706185d4b_tese-jaguar-poulation-dynamics.pdf [accessed 16 August 2014].

Ribeiro, M.C., Metzger, J.P., Martensen, A.C., Ponzoni, F.J. \& Hirota, M.M. (2009) The Brazilian Atlantic Forest: how much is left, and how is the remaining forest distributed? Implications for conservation. Biological Conservation, 142, 1141-1153.

Salom-Pérez, R., Carrillo, E., SÁenz, J.C. \& Mora, J.M. (2007) Critical condition of the jaguar Panthera onca population in Corcovado National Park, Costa Rica. Oryx, 41, 51-56.

Sanderson, E.W., Redford, K.H., Chetkiewicz, C.-L., Medellin, R.A., Rabinowitz, A.R., Robinson, J.G. \& Taber, A.B. (2002) Planning to save a species: the jaguar as a model. Conservation Biology, 16, 58-72.

Schaller, G.B. (1972) The Serengeti Lion: A Study of Predator-Prey Relations. University of Chicago Press, Chicago, USA.

SEBER, G.A.F. (1965) A note on the multiple-recapture census. Biometrika, 52, 249-259.

Seymour, K.L. (1989) Panthera onca. Mammalian Species, 340, 1-9. Silveira, L. \& Crawshaw, JR, P. (2008). Panthera onca Linnaeus, 1758. In Livro Vermelho da Fauna Brasileira Ameaçada de Extinção (eds A.B.M. Machado, G.M. Drummond \& A.P. Paglia), pp. 793794. Ministério do Meio Ambiente and Fundação Biodiversitas, Brasília and Belo Horizonte, Brazil.

Silver, S.C., Ostro, L.E.T., Marsh, L.K., Maffei, L., Noss, A.J., Kelly, M.J. et al. (2004) The use of camera traps for estimating jaguar (Panthera onca) abundance and density using capture/ recapture analysis. Oryx, 38, 148-154.

Soisalo, M.K. \& Cavalcanti, S.M.C. (2006) Estimating the density of a jaguar population in the Brazilian Pantanal using camera-traps and capture-recapture sampling in combination with GPS radiotelemetry. Biological Conservation, 129, 487-496.

Sollmann, R., Furtado, M.M., Gardner, B., Hofer, H., Jácomo, A.T.A., Tôrres, N.M. \& Silveira, L. (2011) Improving density estimates for elusive carnivores: accounting for sexspecific detection and movements using spatial capture-recapture models for jaguars in central Brazil. Biological Conservation, 144, 1017-1024.

Srbek-Araujo, A.C. (2013) Conservação da Onça-pintada (Panthera onca Linnaeus, 1758) na Mata Atlântica de Tabuleiro do Espírito Santo. PhD thesis. Universidade Federal de Minas Gerais, Belo Horizonte, Brazil. Http://www.icb.ufmg.br/pgecologia/teses/T94_ Ana_Araujo.pdf [accessed 16 August 2014].

Srbek-Araujo, A.C. \& Chiarello, A.G. (2005) Is camera-trapping an efficient method for surveying mammals in Neotropical forests?
A case study in south-eastern Brazil. Journal of Tropical Ecology, 21, 121-125.

Srbek-Araujo, A.C. \& Chiarello, A.G. (2013) Influence of cameratrap sampling design on mammal species capture rates and community structures in southeastern Brazil. Biota Neotropica, $13,51-62$.

Srbek-Araujo, A.C., Mendes, S.L. \& Chiarello, A.G. (2015) Jaguar (Panthera onca Linnaeus, 1758) roadkill in Brazilian Atlantic Forest and implications for species conservation. Brazilian Journal of Biology, 75, 581-586.

Stanley, T.R. \& Burnham, K.P. (1999) A closure test for time-specific capture-recapture data. Environmental and Ecological Statistics, 6, 197-209.

Torre, J.A. \& Medellín, R.A. (2011) Jaguars Panthera onca in the Greater Lacandona Ecosystem, Chiapas, Mexico: population estimates and future prospects. Oryx, 45, 546-553.

Tôres, N.M., Marco, Jr, P., Diniz Filho, J.A.F. \& Silveira, L. (2008) Jaguar distribution in Brazil: past, present and future. Cat News Special Issue, 4, 4-8.

Trolle, M. \& Kéry, M. (2005) Camera-trap study of ocelot and other secretive mammals in the northern Pantanal. Mammalia, 69, 405-412.

Utida, S. (1957) Population fluctuation, an experimental and theoretical approach. Cold Spring Harbor Symposium on Quantitative Biology, 22, 139-151.

Wallace, R.B., Gomez, H., Ayala, G. \& Espinoza, F. (2003) Camera trapping for jaguar (Panthera onca) in the Tuichi Valley, Bolivia. Mastozoologia Neotropical/Journal of Tropical Mammalogy, 10, 133-139.

White, G.C., Anderson, D.R., Burnham, K.P. \& Otis, D.L. (1982) Capture-recapture and Removal Methods for Sampling Closed Populations. Los Alamos National Laboratory, Los Alamos, USA.

White, G.C. \& Burnham, K.P. (1999) Program MARK: survival estimation from populations of marked animals. Bird Study, 46 (Suppl.), 120-138.

Zeller, K.A. (2007) Jaguars in the New Millennium Data Set Update: The State of the Jaguar in 2006. Wildlife Conservation Society, New York, USA. Http://www.catsg.org/fileadmin/filesharing/3. Conservation_Center/3.2._Status_Reports/Jaguar/Zeller_2007_ Jaguars_in_the_new_Millenium_Update.pdf [accessed 16 August 2014].

\section{Biographical sketches}

This study is part of the research project Population Size, Density and Habitat Use by Jaguar (Panthera onca, Carnivora, Felidae) in Reserva Natural Vale, Linhares, Espírito Santo/Brazil, which began in 2005 and aims to contribute to the conservation of the jaguar in the Atlantic Forest. Ana Carolina Srbek-Araujo is interested in the ecology and conservation of Neotropical vertebrates, especially mammals. Adriano Chiarello is interested in the ecology and conservation of Neotropical mammals and birds. 